\title{
Pengaruh Kualitas Sumber Daya Manusia dan Pengawasan Terhadap Produktivitas Karyawan Pada Hotel Santika Palembang
}

\author{
Agustina $^{1}$, Ninin Non Ayu Salmah ${ }^{2}$ \\ ${ }^{1}$ Fakultas Ekonomi dan Bisni Universitas PGRI Palembang \\ ${ }^{2}$ Fakultas Ekonomi dan Bisnis Universitas PGRI Palembang, nininsalmah@univpgri-palembang.ac.id
}

\begin{abstract}
ABSTRAK
Penelitian ini bertujuan untuk mengetahui pengaruh kualitas sumber daya manusia dan pengawasan terhadap produktivitas karyawan pada Hotel Santika Palembang. Metode penelitian adalah metode verifikatif dengan populasi adalah seluruh karyawan Hotel Santika Palembang yang berjumlah 53 Karyawan. Teknik pengambilan sampel adalah sampel sensus sehingga jumlah sampel sebanyak 53 responden. Teknik pengumpulan data adalah kuisoner. Teknik uji coba instrumen menggunakan uji validitas dan uji reliabilitas dengan Skala Likert sebagai skala. Teknik analisis data menggunakan analisis regresi linier berganda yang didahului uji asumsi klasik, analisis koefisien determinasi dan pengujian hipotesis. Hasil penelitian adalah 1)secara simultan kualitas sumber daya manusia dan pengawasan berpengaruh signifikan terhadap produktivitas karyawan; 2)secara parsial kualitas sumber daya manusia berpengaruh signifikan terhadap produktivitas karyawan; dan 3)secara parsial pengawasan berpengaruh signifikan terhadap produktivitas karyawan.
\end{abstract}

Kata kunci : kualitas sumber daya manusia, pengawasan, produktivitas

\section{ABSTRACT}

This study aims to determine the effect of the quality of human resources and supervision on employee productivity at Hotel Santika Palembang. The research method is a verification method with a population of 53 employees of Hotel Santika Palembang. The sampling technique was a census sample so that the number of samples was 53 of samples was 53 respondents. The data collection technique is a questionnaire. The instrument testing technique uses validity and reliability tests with a Likert scale as a scale. The data analysis technique used multiple linear regression analysis which was preceded by classical assumption test, coefficient of determination analysis and hypothesis testing. The results of the study are 1)simultaneously the quality of human resources and supervison have a significant effect on employee productivity; 2)partially the quality of human resources has a significant effect on employee productivity; and 3)partially supervision has a significant effect on employee productivity.

Keywords : quality of human resources, supervisoion, productivity

\section{A. PENDAHULUAN}

Persaingan antar perusahaan pada saat ini menuntut perusahaan harus mampu bertahan dan berkompetisi dengan perusahaan lain. Pelanggan menuntut produk sesuai yang dijanjikan. Pada saat ini hampir tidak ada produk yang murni berupa barang, tetapi barang hampir selalu mendapatkan imbuhan jasa atau pelayanan ketika sampai di tangan pelanggan akhir. Perusahaan pada saat ini bertumpu pada kualitas sumber daya manusia yang dimiliki.. Peranan sumber daya manusia penting karena merupakan salah satu penggerak seluruh kegiatan atau aktivitas perusahaan dalam mencapai tujuannya baik memperoleh keuntungan maupun untuk mempertahankan kelangsungan hidup perusahaan dengan harapan tujuan perusahaan akan tercapai dengan baik. Tingginya tuntutan pelanggan pada saat ini terhadap produk yang dihasilkan perusahaan menuntut karyawan yang mampu bekerja secara profesional. Perusahaan membutuhkan karyawan yang dapat 
diandalkan melalui kemampuan dan kesiapan pada saat bekerja sehingga tercapai produktivitas optimal.. Werther dan Davis dalam Sutrisno (2015:4) menjelaskan kualitas sumber daya manusia adalah menyangkut pegawai yang siap, mampu, dan siaga dalam tujuan perusahaan.

Sumber daya manusia memerlukan pengawasan dalam bekerja agar produktivitas yang menjadi target perusahaan dapat dicapai. Dengan adanya pengawasan dapat mencegah terjadinya penyimpangan, pemborosan, penyelewengan, hambatan, kesalahan, kegagalan dalam mencapai tujuan dan tugas dalam organisasi. Pengawasan merupakan salah satu fungsi manajemen yang perlu diupayakan dalam mencapai tujuan organisasi yang efektif dan efisien. Stoner dkk (2012:317) mengemukakan pengawasan adalah proses dalam menetapkan ukuran kerja dan pengambilan tindakan yang dapat mendukung pencapaian hasil dengan sesuai kinerja yang telah ditetapkan.

Produktivitas kerja merupakan hal yang sangat penting dalam setiap perusahaan untuk mengembangkan diri, meningkatkan kemampuan kerja sehingga tercapai output atau hasil sesuai dengan sasaran target. Hasibuan (2017:94) mangatakan produktivitas adalah perbandingan antara output (hasil) dengan input (masukan), dimana output harus memiliki nilai tambah dan teknik pekerjaan yang lebih baik.

Produktivitas menjadi aspek yang diperhatikan Hotel Santika Palembang melalui peningkatan kualitas sumber daya manusia dan pengawasan. Pelatihan ditujukan untuk meningkatkan keterampilan karyawan, selain itu untuk menselaraskan perkembangan pengetahuan karyawan dengan perkembangan tren industri perhotelan. Pengawasan ditujukan agar pelaksanaan tugas karyawan sesuai dengan peraturan yang ditentukan perusahaan yang berdampak pada baiknya kualitas pekerjaan karyawan. Pengetahuan dan keterampilan yang meningkat disertai pengawasan yang sesuai dengan prosedur akan memberikan peningkatan pada produktivitas karyawan.

Berkaitan dengan hal tersebut, penelitian ini bertujuan untuk mengetahui 1). Pengaruh kualitas SDM dan pengawasan secara simultan terhadap produktivitas karyawan pada Hotel Santika Palembang; 2). Pengaruh kualitas SDM secara parsial terhadap produktivitas karyawan pada Hotel Santika Palembang; dan 3). Pengaruh pengawasan secara parsial terhadap produktivitas karyawan pada Hotel Santika Palembang.

\section{B. KAJIAN TEORI}

\section{1) Kualitas Sumber Daya Manusia}

Ndraha (2012:4) mengemukakan kualitas sumber daya manusia adalah mampu menciptakan nilai komparatif bukan saja nilai kompetitif-generatif-inovatif dengan menggunakan energi tertinggi seperti intelligence, creativity, dan imagination tidak lagi semata-mata menggunakan energi kasar, seperti bahan mentah, lahan, air, tenaga otot,dan sebagainnya. Kualitas sumber daya manusia adalah kemampuan dalam menjalankan tugas dan tanggung jawab yang diberikan kepada nya agar perusahaan mampu bersaing.

Tujuan pengembangan kualitas sumber daya manusia menurut Sedarmayanti (2017:155) adalah :

$\checkmark$ menyiapkan seseorang agar pada saatnya diberi tugas tertentu mampu menyelesaiakan tugas; 
$\checkmark \quad$ memperbaiki kondisi seseorang yang sudah diberi tugas dan sedang menghadapi tugas tertentu;

mempersiapkan seseorang yang diberi tugas tertentu yang syaratnya lebih berat dari tugas yang dikerjakan;

$\checkmark \quad$ melengkapi seseorang dengan hal yang mungkin timbul disekitar tugasnya;

$\checkmark \quad$ menyesuaikan seseorang kepada tugas yang mengalami perubahan;

$\checkmark \quad$ menambah keyakinan dan percaya diri kepada seseorang; dan

$\checkmark \quad$ meningkatkan wibawa seseorang dari pandangan bawahan ataupun orang lain baik teman sejawat maupun para relasinya.

\section{2) Pengawasan}

Hadibroto dalam Fahmi (2016:128) mengatakan bahwa pengawasan adalah kegiataan penilaian terdapat organisasi/kegiataan dengan tujuan agar organisasi/kegiataan tersebut melaksanakan fungsinya dengan baik dan dapat memenuhi tujuannya yang telah ditetapkan. Pengawasan adalah suatu rangkaian kegiataan dalam kerja personil dengan menggunakan metode dan alat dalam mencapai tujuan yang telah ditetentukan sebelumnya, apabila terjadinya penyimpangan dan kesalahan dalam melaksanakan tugas bisa diadakan tindakan perbaikan, sehingga tujuan yang telah ditetapkan bisa tercapai sesuai dengan rencana.

Winardi dalam Kadarsiman (2012:194) menjelaskan fungsi pengawasan yaitu:

a) menetapkan tujuan dan merencanakan bagaimana mencapainya;

b) menentukan beberapa banyak karyawan yang diperlukan dalam keterampilan yang perlu dimiliki mereka;

c) menyeleksi individu untuk mengisi posisi (staffing) kemudian diberikan tugas kerja untuk membantu mereka yang bertanggung jawab untuk melaksanakan tugas dengan baik; dan

d) meneliti baik rencana yang dilaksanakan maupun mempelajari lagi rencana berhubungan dengan hasil yang dicapai dalam rencana dimodifikasi.

Saydam dalam Kadarisman (2012:205) mengemukakan jenis-jenis pengawasan yaitu :

$>$ pengawasan fungsional, untuk mengawasi pelaksanaan tugas-tugas yang ditentukan;

> pengawasan masyarakat, pengawasan ini dilakukan dengan cara disampaikan kepada masyarakat dengan cara lisan maupun tulisan dengan melalui media cetak; dan

$>$ pengawasan melekat, untuk meningkatkan disiplin, prestasi kerja, dan pencapaian sasaran pelaksanaan pekerjaan.

\section{3) Produktivitas}

Tohardi dalam Sutrisno (2015:100) mengatakan bahwa produktivitas kerja sebagai sikap mental dalam mencari perbaikan terhadap yang telah ada. Suatu keyakinan bahwa seseorang dapat melakukan pekerjaan lebih baik dari hari ini ataupun hari kemarin dan hari esok lebih baik dari hari ini.Produktivitas memberikan pengertian selalu memberikan hasil yang lebih baik di masa mendatang sehingga keryawan dalam perusahaan selalu berupaya mengembangkan diri.

Sedarmayanti (2017:343) menjelaskan faktor yang mempengaruhi produktivitas karyawan yaitu :

a) pendidikan; 
b) keterampilan;

c) disiplin;

d) sikap mental dan etika kerja;

e) motivasi;

f) gizi dan Kesehatan;

g) tingkat penghasilan;

h) jaminan sosiall;

i) lingkungan dan iklim kerja;

j) hubungan industrial Pancasila;

k) teknologi;

I) Sarana Produksi;

m) manajemen;

n) kesempatan berprestasi.

Siagian dalam Sutrisno (2015:105) mengemukakan upaya perbaikan produktivitas yaitu :

$>$ perbaikan terus-menerus;

$>$ peningkatan mutu hasil pekerjaan; dan

$>$ pemberdayaan sumber daya manusia.

\section{4) Hipotesis Penelitian}

Berkaitan dengan pengaruh kualitas sumber daya manusia dan pengawasan terhadap produktivitas karyawan, maka dirumuskan hipotesis penelitian yaitu 1). secara simultan kualitas sumber daya manusia dan pengawasan berpengaruh signitifikan terhadap produktivitas karyawan di Hotel Santika Palembang; 2). secara parsial kualitas sumber daya manusia berpengaruh signitifikan terhadap produktivitas karyawan di Hotel Santika Palembang; dan 3). secara parsial pengawasan berpengaruh signitifikan terhadap produktivitas karyawan Hotel Santika Palembang.

\section{METODE PENELITIAN}

1) Objek dan Lokasi Penelitian

Penelitian ini dilaksanakan di Hotel Santika Radial dengan alamat Jalan . Radial No. 168824 Ilir Kecamatan Bukit Kecil Kota Palembang Sumatera Selatan.

2) Metode Penelitian

Penelitian ini menggunakan metode verifikatif yang menguji kebenaran keterkaitan antara analisis jabatan dan desain pekerjaan dengan perencanaan sumber daya manusia. Muharto dan Arisandy (2016:33) mendefinisikan penelitian verifikatif sebagai penelitian yang bertujuan untuk menguji kebenaran suatu pengetahuan.

3) Variabel dan Definisi Operasional Penelitian

Variabel dalam penelitian ini meliputi variabel bebas dan variabel terikat. Variabel bebas yaitu kualitas sumber daya manusia dengan simbol $X_{1}$ dan pengawasan dengan simbol $\mathrm{X}_{2}$. Variabel terikat yaitu produktivitas dengan simbol $\mathrm{Y}$. Variabel kualitas sumber daya manusia didefinisikan sebagai kemampuan dalam menjalankan tugas dan tanggung jawab yang diberikan kepadanya agar perusahaan mampu bersaing. Indikator variabel kualitas sumber daya manusia (Sedarmayanti, 2017:160) yaitu:

a. kemampuan fisik (kecerdasan);

b. kemampuan inteketual (kecerdasan); 
c. kemampuan psikologis (mental).

Variabel pengawasan didefinisikan sebagai suatu rangkaian kegiataan dalam kerja personil dengan menggunakan metode dan alat dalam mencapai tujuan yang telah ditetentukan sebelumnya, apabila terjadinya penyimpangan dan kesalahan dalam melaksanakan tugas bisa diadakan tindakan perbaikan, sehingga tujuan yang telah ditetapkan bisa tercapai sesuai dengan rencana. Indikator variabel pengawasan (Fahmi, 2016:205) yaitu :
a. menetapkan standar;
b. menentukan pengukuran;
c. mengukur kinerja;
d. perbandingan pelaksanaan; dan
e. pengambilan keputusan memenuhi tujuan yang telah ditetapkan.

Variabel produktivitas didefinisikan sebagai sikap mental yang selalu mempunyai pandangan kehidupan untuk menjadi lebih baik lagi dari hari kemarin dan esok harus lebih dari hari ini, dengan demikian seseorang untuk tidak cepat puas, akan tetapi harus mengembangkan diri dan meningkatkan kememapuan kerja dengan cara mencari perbaikan-perbaikan dan peningkatan. Indikator variabel produktivitas (Sutrisno, 2015:104) yaitu :

$>$ kemampuan;

$>$ meningkatkan hasil yang dicapai;

$>$ semangat kerja;

$>$ pengembangan diri;

$>$ mutu; dan

$>$ efisiensi.

4) Populasi dan Sampel

Populasi dalam penelitian ini adalah seluruh karyawan tetap Hotel Santika Palembang berjumlah 53 karyawan. Teknik pengambilan sampel adalah sampel jenuh (sensus) dimana seluruh anggota anggota populasi menjadi anggota sampel sehingga jumlah sampel sebanyak 53 responden.

5) Sumber Data dan Teknik Pengumpulan Data

Sumber data dalam penelitian adalah data primer yang diperoleh secara langsung dari tempat atau objek dan memberikan data langsung kepada pengumpul data. Teknik pengumpulan data dalam penelitian adalah kuesioner dengan memberi seperangkat pertanyaan tertulis kepada responden untuk dijawab.

6) Skala Pengukuran

Skala pengukuran dalam penelitian ini menggunakan skala Likert. Jawaban yang diperoleh berdasarkan kuisioner dikuantifikasi dalam bentuk skor yaitu Sangat Setuju dengan skor 5, Setuju dengan skor 4, Ragu-Ragu dengan skor 3, Tidak Setuju dengan skor 2 dan Sangat Tidak Setuju dengan skor 1.

7) Uji Coba Instrumen

Uji coba instrumen penelitian dilakukan dengan uji validitas dan uji reliabilitas. Uji validitas dilakukan dengan cara mengkorelasikan skor item dengan skor total item tiap variabel kemudian membandingkan nilai tersebut dengan a pada 0,05 , kriteria pengujian adalah 1)jika Sig<a maka instrumen memiliki validitas yang baik dan 2)jika Sig>a maka instrumen tidak memiliki validitas yang baik, nilai $\alpha$ sebesar 0,05 . Uji 
reliabilitas menggunakan Cronbach's Alpha dengan criteria 1)jika nilai Cronbach's Alpha $>0,60$ maka butir kuisioner reliabel dan 2)jika nilai Cronbach's Alpha<0,60 maka butir kuisioner dinyatakan tidak reliabel.

8) Teknik Analisis Data

Teknik analisis data dalam penelitian ini menggunakan regresi linear berganda yang didahului uji asumsi klasik, koefisien determinasi dan uji hipotesis. Uji asumsi klasik meliputi uji normalitas, uji multikolinearitas dan uji heterokedastisitas. Uji normalitas dilakukan dengan uji Kolmogorov-Smirnov dengan kriteria 1). jika nilai Sig<0,05 maka data dikatakan tidak berdistribusi normal dan 2). jika Sig>0,05 maka data dikatakan berdistribusi normal. Uji multikolinearitas dilakukan dengan melihat nilai tolerance dan VIF dengan kriteria 1). jika nilai tolerance $>0,1$ dan $\mathrm{VIF}<10$, maka tidak terjadi gejala multikolinearitas dan 2). jika nilai tolerance $<0,1$ dan $\mathrm{VIF}>10$, maka terjadi gejala multikolinearitas. Uji heterokedastisitas dilakukan dengan melihat pola titik-titik pada scatterplot dengan kriteria 1). jika titik-titik menyebar dengan pola yang tidak jelas dan dibawah atau di atas angka 0 pada sumbu $Y$, maka tidak terjadi gejala heteroskedastisitas dan 2). jika titik-titik menyebar dengan pola yang jelas dan mengikuti arah sumbu Y, maka terjadi gejala heteroskedastisitas.

Analisis regresi linear berganda digunakan untuk menentukan ketepatan prediksi apakah ada pengaruh variabel bebas analisis jabatan dan desain pekerjaan terhadap perencanaan sumber daya manusia. Regresi linear berganda dirumuskan dengan $Y=a+b_{1} X_{1}+b_{2} X_{2}$ dimana a adalah konstanta, $b_{1}$ adalah koefisien regresi dengan variabel $X_{1}, b_{2}$ adalah koefisien regresi dengan variabel $X_{2}, X_{1}$ adalah variabel kualitas sumber daya manusia, $X_{2}$ adalah variabel pengawasan dan $Y$ adalah variabel produktivitas. Koefisien determinasi $\left(R^{2}\right)$ digunakan untuk mengetahui kontribusi variabel bebas terhadap variabel terikat dalam model regresi.

Pengujian hipotesis dilakukan secara simultan (uji F) dan parsial (uji t). Pengujian hipotesis secara simultan digunakan untuk mengetahui signifikansi pengaruh semua variabel bebas terhadap variabel terikat dengan kriteria pengambilan keputusan yaitu 1). jika nilai Sig $>0,05$ maka Ho diterima yang berarti secara simultan terdapat pengaruh yang tidak signifikan variabel-variabel bebas terhadap variabel terikat dan 2). jika nilai Sig<0,05 maka Ho ditolak dan Ha diterima yang berarti secara simultan terdapat pengaruh yang signifikan variabel-variabel bebas terhadap variabel terikat. Pengujian hipotesis secara parsial digunakan untuk menguji signifikansi pengaruh variabel bebas secara parsial terhadap variabel terikat dengan kriteria 1). jika nilai Sig $>0,05$ maka Ho diterima yang berarti secara parsial terdapat pengaruh yang tidak signifikan variabel bebas terhadap variabel terikat dan 2). jika nilai Sig $<0,05$ maka Ho ditolak dan Ha diterima yang berarti secara parsial terdapat pengaruh yang signifikan variabel bebas terhadap variabel terikat.

\section{HASIL PENELITIAN}

\section{Karakteristik Responden}

Karakteristik responden dalam penelitian ini meliputi jenis kelamin, usia dan tingkat pendidikan Distribusi karyawan Hotel Santika berdasarkan jenis kelamin adalah laki-laki berjumlah 37 orang (69\%) dan perempuan berjumlah 16 orang (31\%), dengan demikian mayoritas karyawan berjenis kelamin laki-laki. Distribusi karyawan Hotel Santika berdasarkan usia adalah berusia 20-29 tahun sebanyak 44 orang (83\%), 30-39 tahun sebanyak 8 orang (15,1\%) dan 40 tahun atau lebih sebanyak 1 orang $(1,9 \%)$, dengan demikian mayoritas karyawan berusia 20-29 tahun. Distribusi 
karyawan Hotel Santika berdasarkan pendidikan dengan pendidikan SMA sebanyak 37 orang $(54,7 \%)$ dan pendidikan Diploma-S1 sebanyak 16 orang (45,3\%).

\section{Uji Instrumen Penelitian}

Hasil uji validitas terhadap butir-butir kuisioner pada variabel-variabel yang terlibat dalam penelitian dimana masing-masing variabel terdiri dari 10 butir kuisioner diperlihatkan pada tabel berikut ini.

Tabel Hasil Uji Validitas

\begin{tabular}{|c|r|r|r|}
\hline Butir & \multicolumn{3}{|c|}{ Variabel } \\
\cline { 2 - 4 } Kuisioner & Kualitas SDM & Pengawasan & Produktivitas \\
\hline 1 & 0,000 & 0,000 & 0,000 \\
\hline 2 & 0,000 & 0,000 & 0,000 \\
\hline 3 & 0,000 & 0,000 & 0,000 \\
\hline 4 & 0,000 & 0,000 & 0,000 \\
\hline 5 & 0,000 & 0,000 & 0,000 \\
\hline 6 & 0,000 & 0,000 & 0,000 \\
\hline 7 & 0,000 & 0,000 & 0,000 \\
\hline 8 & 0,000 & 0,000 & 0,000 \\
\hline 9 & 0,000 & 0,000 & 0,000 \\
\hline 10 & 0,000 & 0,000 & 0,000 \\
\hline
\end{tabular}

Sumber : Data diolah, 2021

Tabel diatas memperlihatkan uji validitas terhadap butir-butir kuisioner pada variabel-variabel yang terlibat dalam penelitian menghasilkan nilai Sig yang lebih kecil dari a pada 0,05, artinya butir-butir kuisoner pada masing-masing variabel penelitiandinyatakan valid sehingga dapat dijadikan instrumen penelitian.

Hasil uji reliabilitas terhadap butir-butir kuisioner pada variabel-variabel yang terlibat dalam penelitian dimana masing-masing variabel terdiri dari 10 butir kuisioner diperlihatkan pada tabel berikut ini.

Tabel Hasil Uji Reliabilitas Variabel Kualitas Sumber Daya Manusia

\begin{tabular}{|l|r|}
\hline \multicolumn{1}{|c|}{ Variabel } & Cronbach's Alpha \\
\hline Kualitas Sumber Daya Manusia & 0,869 \\
\hline Pengawasan & 0,868 \\
\hline Produktivitas & 0,906 \\
\hline
\end{tabular}

Sumber : Data diolah, 2021

Tabel tersebut memperlihatkan uji reliabilitas terhadap butir-butir kuisioner menghasilkan nilai Cronbach's Alpha untuk variabel kualitas sumber daya manusia sebesar 0,869,variabel pengawasan sebesar 0,868 dan variabel produktivitas sebesar 0,906, Nilai Cronbach's Alpha masing-masing variabel yang terlibat dalam penelitian memperlihatkan nilai yang lebih besar dari batas penerimaan uji reliabilitas sebesar 0,60, maka butir-butir kuisioner yang dijadikan indikator pada masingmasing variabel dapat dijadikan instrumen penelitian.

\section{Uji Asumsi Klasik}

Uji asumsi klasik dilakukan sebelum analisis regresi linear berganda dengan persyaratan data berdistribusi normal, tidak terdapat gejala multikolinearitas dan 
heteroskedastisitas pada data penelitian. Hasil uji normalitas diperlihatkan pada tabel berikut ini.

Tabel Hasil Uji Normalitas

\begin{tabular}{|l|l|r|}
\hline \multicolumn{2}{|l|}{} & Unstandardized Residual \\
\hline N & Mean & 53 \\
\hline Normal Parameters & .0000000 \\
\hline & Std. Deviation & 2.42074529 \\
\hline Most Extreme Differences & Absolute & .098 \\
\hline & Positive & .098 \\
\hline & Negative & -.071 \\
\hline Kolmogorov-Smirnov Z & .098 \\
\hline Asymp. Sig. (2-tailed) & .200 \\
\hline
\end{tabular}

Sumber : Data diolah, 2021

Tabel diatas memperlihatkan uji normalitas menghasilkan nilai Asymp. Sig. (2tailed) sebesar 0,200 atau lebih besar dari 0,05 maka dapat dinyatakan data berdistribusi normal.

Hasil uji multikolinearitas diperlihatkan pada tabel berikut ini.

Tabel Hasil Uji Multikolinearitas

\begin{tabular}{|l|r|r|}
\hline \multicolumn{1}{|c|}{ Variabel } & Tolerance & \multicolumn{1}{c|}{ VIF } \\
\hline Kualitas Sumber Daya Manusia & .543 & 1.842 \\
\hline Pengawasan & .543 & 1.842 \\
\hline
\end{tabular}

Sumber : Data diolah, 2021

Tabel tersebut memperlihatkan nilai tolerance pada variabel kualitas sumber daya manusia sebesar 0,543 atau lebih besar dari 0,1 dan nilai VIF sebesar 1,842 atau lebih kecil dari 10 , demikian juga nilai tolerance pada variabel pengawasan sebesar 0,543 atau lebih besar dari 0,1 dan nilai VIF sebesar 1,842 atau lebih kecil dari 10. Dengan demikian dapat dinyatakan data penelitian terbebas dari gejala multikolinearitas.

Hasil uji heteroskedastisitas diperlihatkan pada gambar berikut ini.

Scatterplot

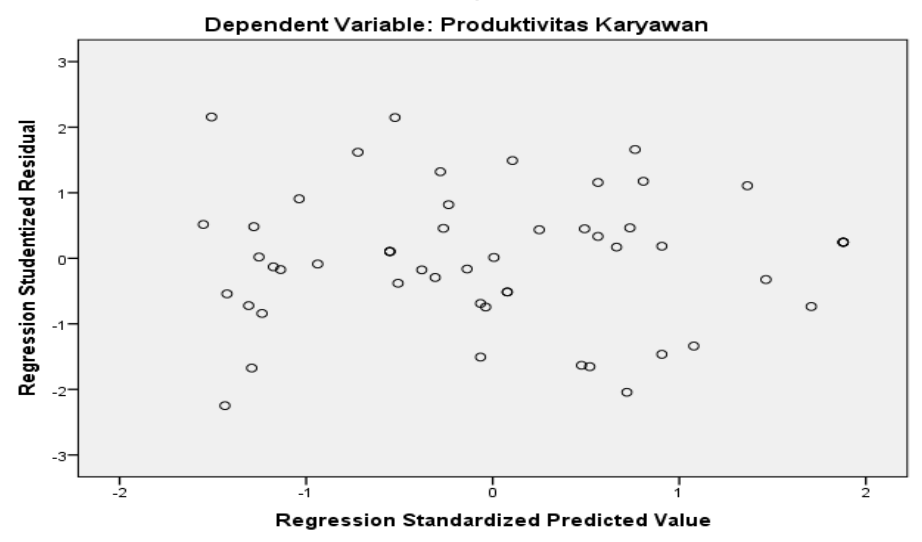

Gambar Hasil Uji Heteroskedastisitas

Sumber : data diolah, 2021

Gambar diatas menunjukkan hasil uji heteroskedastisitas yang memperlihatkan titik-titik menyebar dan tidak mempunyai pola tertentu sehingga dapat dinyatakan idak terjadi masalah heteroskedastisitas pada data penelitian. 


\section{Analisis Regresi Linear Berganda}

Tabel berikut ini memperlihatkan output regresi linear berganda.

Tabel Output Regresi Linear Berganda

\begin{tabular}{|l|r|}
\hline \multicolumn{1}{|c|}{ Model } & B \\
\hline Constant & 1.048 \\
\hline Kualitas Sumber Daya Manusia & .682 \\
\hline Pengawasan & .268 \\
\hline
\end{tabular}

Sumber : Data diolah, 2021

Tabel diatas memperlihatkan output regresi linier berganda sehingga diatas dapat dirumuskan persamaan $Y=1,048+0,682 X_{1}+0,286 X_{2}$. Nilai konstanta a sebesar 1,408 menunjukkan apabila tidak terdapat variabel kualitas sumber daya manusia dan variabel pengawasan Palembang maka variabel produktivitas karyawan Hotel Santika Palembang sebesar 1,408 satuan.

Koefisien regresi $b_{1}$ dengan variabel bebas kualitas sumber daya manusia sebesar 0,682 dan bertanda positif menunjukkan bahwa jika kualitas sumber daya manusia meningkat sebesar 1 satuan maka produktivitas karyawan Hotel Santika Palembang akan meningkat sebesar 0,682 satuan, sebaliknya jika kualitas sumber daya manusia menurun sebesar 1 satuan maka produktivitas karyawan Hotel Santika Palembang menurun sebesar 0,682 satuan, dengan asumsi variabel pengawasan konstan. Koefisien regresi $b_{2}$ dengan variabel bebas pengawasan sebesar 0,286 dan bertanda positif menunjukkan bahwa jika pengawasan meningkat sebesar 1 satuan maka produktivitas karyawan Hotel Santika Palembang akan meningkat sebesar 0,286 satuan, sebaliknya jika pengawasan menurun sebesar 1 satuan maka produktivitas karyawan Hotel Santika Palembang menurun sebesar 0,286 satuan, dengan asumsi variabel kualitas sumber daya manusia konstan.

\section{Analisis Koefisien Determinasi}

Hasil analisis koefisien determinasi diperlihatkan pada tabel berikut ini.

\begin{tabular}{|c|c|}
\multicolumn{2}{|c|}{ Tabel Koefisien Determinasi } \\
\hline Model & $\mathbf{R}^{2}$ \\
\hline Regression & .730 \\
\hline
\end{tabular}

Sumber : Data diolah, 2021

Tabel memperlihatkan koefisien determinasi sebesar 0,730, artinya kontribusi variabel bebas kualitas sumber daya manusia dan pengawasan karyawan terhadap produktivitas karyawan Hotel Santika Palembang sebesar $73 \%$ sisanya $27 \%$ disumbangkan oleh variabel lain yang tidak dianalisis dalam model regresi. Variabel tersebut diantaranya motivasi, kompetensi dan kompensasi.

\section{Pengujian Hipotesis}

Hasil uji F diperlihatkan pada tabel berikut ini.

Tabel Hasil Uji F

\begin{tabular}{|c|c|}
\hline Model & Sig \\
\hline Regression & .000 \\
\hline
\end{tabular}

Sumber: Data diolah, 2021 
Tabel diatas memperlihatkan nilai signifikan sebesar 0,000 atau lebih kecil dari a pada 0,05 , artinya Ho ditolak dan $\mathrm{Ha}$ diterima maka dapat disimpulkan bahwa secara simultan kualitas sumber daya manusia dan pengawasan berpengaruh signitifikan terhadap produktivitas karyawan pada Hotel Santika Palembang.

Hasil uji t dengan variabel kualitas sumber daya manusia dan pengawasan diperlihatkan pada tabel berikut ini.

Tabel Hasil Uji t

\begin{tabular}{|l|l|}
\hline \multicolumn{1}{|c|}{ Variabel } & Sig \\
\hline Kualitas Sumber Daya Manusia & .000 \\
\hline Pengawasan & .016 \\
\hline
\end{tabular}

Sumber: Data diolah, 2021

Tabel diatas memperlihatkan uji t dengan variabel bebas kualitas sumber daya manusia menghasilkan nilai signifikan sebesar 0,000 atau lebih kecil dari a pada 0,05, artinya Ho ditolak dan Ha diterima maka dapat disimpulkan bahwa secara parsial kualitas sumber daya manusia berpengaruh signitifikan terhadap produktivitas karyawan pada Hotel Santika Palembang. Uji t dengan variabel bebas pengawasan menghasilkan nilai signifikan sebesar 0,016 atau lebih besar dari a pada 0,05, artinya Ho diterima maka dapat disimpulkan bahwa secara parsial pengawasan berpengaruh tidak signifikan terhadap produktivitas karyawan pada Hotel Santika Palembang.

\section{E. PEMBAHASAN}

Pengujian hipotesis secara simultan menghasilkan penolakan Ho dan penerimaan Ha sehingga dapat disimpulkan secara simultan kualitas sumber daya manusia dan pengawasan terhadap produktivitas karyawan Hotel Santika. Hasil penelitian ini sejalan dengan penelitian terdahulu yang dilakukan oleh Syafitri dan Chairoel (2019) dan Sulviadi (2021) yang menyatakan bahwa secara simultan kualitas sumber daya manusia dan pengawasan berpengaruh signifikan terhadap produktivitas karyawan.

Pengujian hipotesis secara parsial menghasilkan penolakan $\mathrm{Ho}$ dan penerimaan $\mathrm{Ha}$ sehingga dapat disimpulkan secara parsial kualitas sumber daya manusia berpengaruh signifikan terhadap produktivitas karyawan Hotel Santika. Hasil penelitian ini tidak sejalan dengan penelitian terdahulu yang dilakukan oleh Syafitri dan Chairoel (2019) yang menyatakan bahwa secara parsial kualitas sumber daya manusia tidak berpengaruh terhadap produktivitas karyawan.

Pengujian hipotesis secara parsial menghasilkan penerimaan Ho sehingga dapat disimpulkan secara parsial pengawasan berpengaruh tidak signifikan terhadap produktivitas karyawan Hotel Santika. Hasil penelitian ini tidak sejalan dengan penelitian yang dilakukan oleh Akila (2017) yang bahwa secara parsial pengawasan berpengaruh terhadap produktivitas karyawan.

\section{F. KESIMPULAN DAN SARAN}

1. Kesimpulan

Berdasarkan hasil analisis data dan pembahasan mengenai pengaruh variabel kualitas sumber daya manusia dan pengawasan baik secara parsial dan simultan dapat ditarik kesimpulan sebagai berikut: 
a) secara simultan kualitas sumber daya manusia dan pengawasan berpengaruh signitifikan terhadap produktivitas karyawan pada Hotel Santika Palembang;

b) secara parsial kualitas sumber daya manusia berpengaruh signitifikan terhadap produktivitas karyawan pada Hotel Santika Palembang;

c) secara parsial pengawasan berpengaruh tidak signifikan terhadap produktivitas karyawan pada Hotel Santika Palembang.

\section{Saran}

Berdasarkan hasil penelitian dan kesimpulan yang telah diuraikan diatas, maka disarankan sebagai berikut:

a) pengawasan hendaknya ditingkatkan lagi, sehingga dapat produktivitas kerja karyawan;

b) untuk meningkatkan produktivitas karyawan pada Hotel Santika Palembang, sebaiknya memperhatikan dalam penerimaan calon tenaga kerja yang berkualitas;

c) sebagai usaha untuk mengembangkan karyawan yaitu melalui pengawasan dengan tujuan meningkatkan kerajinan dalam menjalankan pekerjaan, ketaatan mematuhi jam kerja, ketaatan pada peraturan perusahaan dalam upaya meningkatkan produktivitas karyawan yang diharapkan perusahaan;

d) untuk penelitian selanjutnya disarankan agar peneliti dapat menambahkan variabel yang berpengaruh seperti disiplin kerja dan motivasi karyawan untuk mendapatkan hasil yang lebih baik.

\section{DAFTAR PUSTAKA}

Akila. (2017). Pengaruh Insentif dan Pengawasan Terhadap Produktivitas Kerja Karyawan Pada CV. Vassel Palembang. Jurnal Ecoment Global. 2(2)

Fahmi, Irham, (2016). Pengantar Manajemen SDM Konsep \& Kinerja. Edisi Pertama. Jakarta :Mitra Wacana

Hasibuan, S.P. Malayu. (2017). Manajemen Sumber Daya Manusia. Jakarta: PT. Bumi Askara.

Kadarisman. (2012). Manajemen Pengembangan Sumber Daya Manusia. Jakarta: Rajawali Pers.

Muharto dan Arisandy, Ambarita. (2016). Metode Penelitian Sistem Informasi. Yogyakarta: Deepublish.

Ndraha, Talizidulu. (2012). Pengantar Teori Pengembangan Sumber Daya Manusia. Jakarta: Rineka Cipta.

Sedarmayanti. (2017). Perencanaan dan Pengembangan SDM Untuk Meningkatkan Kompetensi Kinerja, Dan Produktivitas Kerja. Bandung: PT. Refika Aditama.

Stoner, James, A., Freeman, F., Gilbert, Jr. (2012). Manajemen. Jakarta : PT. Prenhallindo. 
Sulviadi, Dana Sefrina, Afi Rahmat Slamet dan Fahrurrozi Rahman. (2021). Pengaruh Pengawasan Kerja, Budaya Kerja, Lingkungan Kerja Dan Kepuasan Kerja Terhadap Produktivitas Kerja Karyawan (Studi Pada Karyawan PT. Nippon Indosari Carpindo Tbk Kabupaten Pasuruan). e-Jurnal Manajemen Fakultas Ekonomi dan Bisnis Unisma, 10 (02). 132-145.

Sutrisno, Edy. (2015). Sumber Daya Manusia. Jakarta: Kencana Prenada.

Syafitri, Tari. JN., \& Lucy Chairoel, L. (2019). Pengaruh Rekrutmen, Seleksi, Penempatan Kerja dan Kualitas SDM Terhadap Produktivitas Kerja (Studi Pada Karyawan Bank Syariah Mandiri Kantor Cabang Padang). Jurnal Benefitta 4(3) Oktober (570-586). 